Anna Dąbrowska

Kazimierz Pulaski University of Technology and Humanities in Radom, Poland ORCID: 0000-0001-7843-3816

angolu@wp.pl

\title{
Influence of the Law of the Council of Europe on Substantive Administrative Law in Poland. Selected Issues
}

\author{
Wpływ prawa Rady Europy na materialne prawo administracyjne \\ w Polsce. Wybrane zagadnienia
}

\section{SUMMARY}

Legislative powers of the Council of Europe have a crucial impact on the domestic legal systems of the EU Member States including substantive administrative law, i.e. such an area of administrative law which defines rights and responsibilities of the public administration bodies and citizens. The legislation created by the Council of Europe's bodies has a great impact on the areas of law which were earlier regarded as the exclusive responsibility of a given country. The Council of Europe has always been a major source of standard setting. This paper analyses selected areas of substantive administrative law taking into account hard law and soft law documents developed under the auspices of the Council of Europe.

Keywords: standards of the Council of Europe; substantive administrative law; Europeanisation of substantive administrative law

\section{INTRODUCTION}

As Z. Duniewska points out, what administrative law is like depends on a number of factors including historical, geographical, natural, and demographic conditions, political system and form of a state and a legal system adopted, accepted values and their graded arrangement. The author adds an important role should be attributed to external factors that determine shape of administrative law. This is corroborated by both distant and closer past and the present. Influence of other states, organizations or international bodies or other entities placed externally may 
be of various forms and scales and may arise from a range of causes ${ }^{1}$. Impact of integration processes, particularly of the European Union, is a special case in point, although influence of the Council of Europe and the associated membership of the Polish state in these structures cannot be ignored either ${ }^{2}$. The relevant literature offers plenty of descriptions of impact of the European Union legislation ${ }^{3}$ on the Polish administrative laws (including its substantive part), whereas effects of the Council of Europe law are neglected. In view of this fact, Z. Duniewska believes a survey of Europeanisation of substantive administrative law $^{4}$ is reasonable given the law-making activities of the organization referred to in the title. The Council of Europe has produced more than 200 multilateral agreements between its member states (often referred to as "European treaties") since its beginnings. A number of these are open to states that are not members of the Council of Europe as well. Besides conventions, the Council of Europe creates documents passed by its statutory

1 Z. Duniewska, W kwestii czynników ksztattujących prawo administracyjne, [in:] Między tradycją a przyszłościa w nauce prawa administracyjnego. Ksiega jubileuszowa dedykowana Profesorowi Janowi Bociowi, red. J. Supernat, Wrocław 2009, p. 120 ff.

2 Political and systemical transformations in Poland that commenced in 1989 paved the way for Poland's participation in structures of the European integration. Poland took appropriate steps to take advantage of this opportunity. It was the first post-communist state to apply for membership of the Council of Europe and undertook to adopt the Convention for the Protection of Human Rights and Fundamental Freedoms. On November 26, 1991, Poland was accepted as a member state of the Council of Europe. See Invitation to the Republic of Poland to Become a Member of the Council of Europe, Resolution (90)18 adopted by the Committee of Ministers, the $446^{\text {th }}$ meeting of Ministers' Deputies, 23 October 1990. As H.P. Furrer noted, the membership of the Council of Europe was not automatic, though. Each country had first to fulfill specific criteria, undergo a predefined procedure, use aid programs offered by the Council of Europe, and become gradually involved in joint actions. It was a kind of acclimatisation designed for the purpose of adjustment to values of the new institutional environment which was in fact time-consuming and took several years in some cases. See H.P. Furrer, Przekraczanie linii podziatów. Wydarzenia polityczne w Radzie Europy od 1989 r - historia i analiza własnych doświadczeń, [in:] Polska i Rada Europy 1990-2005, red. H. Machińska, Warszawa 2005, p. 14. See also J. Jaskiernia, Wptyw Rady Europy na proces transformacji w Polsce, [in:] Młode demokracje. 20 lat transformacji systemowej w Europie Środkowej. Płaszczyzna gospodarcza i polityczna, red. W. Saletra, J. Jarosiński, Kielce 2010, pp. 24 ff.

3 See more on this topic in: G. Krawiec, Europejskie standardy zwiazane z przebiegiem postepowania administracyjnego, „Roczniki Administracji i Prawa” 2011, R. XI, pp. 69-85; J. Jagielski, Europeizacja prawa administracyjnego materialnego (na przykładzie prawa migracyjnego), [in:] Europeizacja polskiego prawa administracyjnego, red. Z. Janku, Z. Leoński, M. Szewczyk, M. Waligórski, K. Wojtczak, Wrocław 2005; J. Boć, Uwagi o prawie administracyjnym w warunkach Unii Europejskiej, [in:] Prawo administracyjne, red. J. Boć, Warszawa 2010; S. Dudzik, B. Iwańska, I. Kawka, Przekształcenia materialnego prawa administracyjnego pod wpływem prawa europejskiego, [in:] System Prawa Administracyjnego, t. 3: Europeizacja prawa administracyjnego, red. Z. Hauser, Z. Niewiadomski, A. Wróbel, Warszawa 2014.

4 For more on the Europeanisation of the substantive administrative law, see A. Dąbrowska, Europeizacja materialnego prawa administracyjnego - wprowadzenie do problematyki, [in:] Złożoność materialnego prawa administracyjnego, red. J. Smarż, Radom 2018, pp. 5-21. 
bodies - the Committee of Ministers and the Advisory Assembly (since 1974 - the Parliamentary Assembly).

It is beyond any doubt the Council of Europe law has considerable impact on the position of domestic legislation in Poland. Administrative law prevailing in Poland has also been largely shaped by international and regional normalisations. This paper, therefore, addresses the Council of Europe's acquis communautaire in respect of substantive administrative law, which is key, as J. Jagielski rightly notes, to the entire administrative legislation as it has formed the essence of administrative law and the mainstream of its normalisations since the very beginnings of development of this branch of law ${ }^{5}$. This text has no ambition to outline the entire subject area of the title. Due to the complexity of this part of administrative law ${ }^{6}$ and the space constraints, the author focuses on identifying selected legal standards.

\section{SOURCES OF THE COUNCIL OF EUROPE'S LEGISLATION}

Endeavours by the Council of Europe to harmonise the member states' legislation arise from the statutory duty of this organization, namely, promoting cooperation among European governments. Sources of the organization's law are of two types: treaty legislation (the uniform name of "the Council of Europe conventions" has been in use since 2005) and soft law ${ }^{7}$ documents, i.e. resolutions and recommendations of the Council of Europe Committee of Ministers ${ }^{8}$ and of the Parliamentary Assembly?

5 J. Jagielski, Rozważania nad pojęciem i istota prawa administracyjnego materialnego, [in:] System Prawa Administracyjnego, t. 7: Prawo administracyjne materialne, red. R. Hauser, Z. Niewiadomski, A. Wróbel, Warszawa 2012, p. 4.

6 Substantive administrative law is the most extensive part of not only administrative law but also of the entire legal system prevailing in Poland as incorporated in a very high number of acts of parliament and even more secondary legislation, as well as the EU normative acts. See Materialne prawo administracyjne, red. M. Miemiec, Warszawa 2013, p. 22.

7 The term was first used in mid-1970s. R. Bierzanek ((,,Miękkie” prawo międzynarodowe, „Sprawy Międzynarodowe" 1987, nr 1, p. 92) attributes it to McNair. On the other hand, G.M. Borchardt and K.C. Wellens (Soft Law in European Community Law, "European Law Review" 1989, Vol. 14, p. 268) claim the term had first been used by P.-M. Dupuy in 1973. According to G.J.H. van Hoof (Rethinking the Sources of International Law, Deventer 1983, p. 187), Dupuy himself stated it had been originated by McNair.

8 See G. de Vel, The Committee of Ministers of the Council of Europe, Strasbourg 1995, p. 15.

9 See more in H. Klebes, Rola Zgromadzenia Parlamentarnego Rady Europy w upowszechnianiu standardów demokratycznych w Europie, [in:] Polska w Radzie Europy. 10 lat członkostwa. Wybrane zagadnienia, red. H. Machińska, Warszawa 2002, p. 30 ff.; J. Jaskiernia, Znaczenie Zgromadzenia Parlamentarnego Rady Europy we wspieraniu demokracji w państwach członkowskich, „Europejski Przegląd Sądowy” 2017, nr 2, pp. 9-15. 
Adoption of treaties is one of the ways serving the organization to carry out the objective laid down in its Statute ${ }^{10}$ (Article 1a). Member states are expected to join conventions approved by the Committee of Ministers, which Article 13 of the Statute defines as "the organ which acts on behalf of the Council of Europe". These treaties contribute to rapprochement of the member states, encouragement of harmonization of law and legal systems, as well as standardization of law on the European scale and setting of minimum legal standards. By creating a shared legal space, the treaties will make the member states more cohesive in democratic, social and cultural terms. In effect, they also facilitate and simplify cooperation among the member states. In fact, a multilateral convention of the Council of Europe can replace a whole series of bilateral agreements between individual states. The extensive subject matter of the conventions it issues affirms the organization addresses all the major current problems of Europe (with the exception of defence) and has become one of the chief platforms for seeking solutions.

The conventions, once ratified, become part of the international hard law and - if a given domestic law stipulates it, which is the case in the Republic of Poland, for instance - are published in a relevant promulgating publication (in Poland it is Journal of Laws) and introduced to a domestic legal order as a source of national hard law, prevailing over the latter in case of conflicts.

Documents compiled by the statutory bodies of the Council of Europe, i.e. the Committee of Ministers and the Parliamentary Assembly, constitute the bulk of the second category of sources for the Council of Europe's legislation. Aside from obligations arising from conventions, actions by the member states should also reflect positions developed by internal bodies of the Council of Europe, including the Steering Committee for Human Rights $(\mathrm{CDDH})^{11}$. Recommendations are typical sources of soft law ${ }^{12}$ - by the way, a little "harder" on the international arena (the Committee of Ministers may request member state governments to report on progress made with the recommendations ${ }^{13}$ ) and very "soft" in the dimension

${ }_{10}$ Statute of the Council of Europe, London, 5 May 1949, European Treaty Series No. 1 (the Polish text: Journal of Laws 1994, No. 118, item 565). See Wybór konwencji Rady Europy, Warszawa 1999, p. 13.

${ }_{11}$ M. Balcerzak, Zalecenia Komitetu Ministrów Rady Europy jako forma pozatraktatowej dziatalności normatywnej i harmonizujacej $w$ dziedzinie praw czlowieka, [in:] Rada Europy - 60 lat na rzecz jedności europejskiej, red. I. Głuszyńska, K. Lankosz, Bielsko-Biała 2009, pp. 6-25.

${ }_{12}$ Soft law comes in an astonishing variety of forms that have eluded attempts at classification so far. Soft law is invoked in relation to, among other things, declarations, resolutions, recommendations, codes of practice, codes of conduct, guidelines, standards, charters, reports, opinions, programs, inter-institutional agreements, as well as soft law disguised as hard law and gentlemen's agreements. See G.M. Borchardt, K.C. Wellens, op. cit., pp. 275-277.

${ }_{13}$ More on the duty to observe the "soft' law, see W. Bańczyk, ,Miękie prawo, ale prawo”, czyli o obowiązk przestrzegania soft law, „Internetowy Przegląd Prawniczy TBŚP UJ” 2016, nr 1, p. $63 \mathrm{ff}$. 
of particular member states ${ }^{14}$. It is worth reflecting on the nature of soft law documents at this junction. They are undoubtedly a step away from the traditional form of governing by the classic means of legally binding instruments. Soft law is a type of social, not legal norm. Although there is no popularly accepted definition of "soft law", it normally denotes any international instrument in writing, other than a treaty, which contains principles, norms, standards or other statements of expected behavior. Soft law expresses a preference, rather than obligation, a state should implement or refrain from acting in certain ways. This explicit preference for certain behaviours is intended to attain functional cooperation among states in order to realise international objectives ${ }^{15}$.

As J. Jaskiernia points out, recommendations are of a different nature than international agreements. Legal force of these normative acts is not equal to international agreements signed as part of the Council of Europe, whose provisions give rise to obligatory undertakings for member states. Given that conclusion of international agreements is as a rule preceded by long preparations and their enforcement requires an equally long process of ratification, the other forms of action by means of "soft law" recommendation instruments become effective substitutes that ensure realization of a number of the Council of Europe's objectives and accelerate achievement of desirable intentions. This justifies the claim that, although norms contained in recommendations are not of a legal force equal to agreements signed as part of the Council of Europe, they may produce desirable substantive effects as opinions in the doctrine suggest they are documents expected to be implemented in member $\operatorname{states}^{16}$.

At a maximum, their authority relies on their "democratic" legitimacy as they express positions of European governments (Committee of Ministers' documents) or of "the European community" (Parliamentary Assembly' documents ${ }^{17}$ ). Despite

${ }^{14}$ H. Izdebski, Rola standardów Rady Europy w dziedzinie organizacji i działania administracji publicznej, [in:] Polska i Rada Europy..., p. 197.

${ }^{15} \mathrm{~K}$. Spryszak, Rola standardów o charakterze soft law w zakresie kreowania zobowiazań w państwach czlonkowskich organizacji międzynarodowych, „Humanities and Social Sciences” 2017, nr 24(4), DOI: https://doi.org/10.7862/rz.2017.hss.77, p. 211.

16 J. Jaskiernia, Standardy Rady Europy a ustrój polityczny Polski, [in:] Polska w Radzie Europy..., p. 106.

17 The Parliamentary Assembly can be seen as an especially useful platform for coordination of actions by Central and Eastern European countries. If the Committee of Ministers is restricted by its diplomatic method that hampers formulation of unambigous positions, members of parliaments in the Parliamentary Assembly suffer from no such limitations. They can express their principled views and take part in solving problems of Central and Eastern Europe. This is particularly true of simmering issues, where parliamentary diplomacy is especially useful. See T. Iwiński, Dyplomacja parlamentarna Rady Europy a rozwiazywanie konfliktów w państwach Europy Środkowej i Wschodniej, [in:] Rada Europy a przemiany demokratyczne w państwach Europy Środkowej $i$ Wschodniej w latach 1989-2009, red. J. Jaskiernia, Torun 2010, p. 759. 
the absence of their legal force, in practice they frequently prove more effective instruments than the so-called hard law acts. Above all, contrary to international conventions, these instruments become effective once they are adopted. In particular, the Committee of Ministers' documents apply to all the Council of Europe member states, whereas conventions bind only the states which have signed and ratified them. A kind of flexibility is their another advantage. A recommendation can be supplemented or amended significantly faster than contents of a convention. From the perspective of implementation of specific principles, recommendations are commonly more effective than treaties. Practice demonstrates states are more eager to carry out provisions of recommendations than to be bound by ratifying conventions ${ }^{18}$. States are occasionally willing to accept more detailed and precise provisions of such instruments that affirm their commitment to a given issue if consequences of failing to perform on such arrangements are limited. In addition, it has already been noted instruments of this type do not require time-consuming and often complicated procedures of agreement to be bound by them on the national scale (this may result in difficulties with securing of financial, public or legislative support needed to realise some undertakings, however). Acts of "soft" law are easier to modify, adapt to new conditions or replace with new documents. Moreover, they are more direct and immediate evidence of international support and consensus than agreements, which are objected to or pend enforcement for long ${ }^{19}$.

A detailed survey of the subject matter of recommendations shows the body is interested in a variety of topics, including issues of bioethics, refugees, corruption, personal data protection, animal protection, culture, education, heritage, sports and youth, environment, local and regional management, and collaboration.

\section{COUNCIL OF EUROPE STANDARDS AND SUBSTANTIVE ADMINISTRATIVE LAW}

This part of the discussion will answer the question of how substantive administrative law ${ }^{20}$ compares to standards created by the Council of Europe. It should be emphasized to begin with effects of the Europeanisation that are most clear in

18 O. Nawrot, Ludzka biogeneza w standardach bioetycznych Rady Europy, Warszawa 2011, pp. 83-84.

19 A.E. Boyle, Some Reflections on the Relationship of Treaties and Soft Law, "International and Comparative Law Quarterly" 1999, Vol. 48(4), DOI: https://doi.org/10.1017/S0020589300063739, pp. 901-903.

${ }^{20}$ Norms contained in prevailing administrative regulations determine rights and duties (conduct) of entities administered as part of administrative legal relations, that is subordinated to entities wielding administrative authority. See Z. Leoński, Materialne prawo administracyjne, Warszawa 2009 , p. 7. 
the area of substantive law. Attempts should be undertaken at more accurate definitions of "substantive law" or "substantive administrative law", which are legal terms. The adjective "substantive" is proof the law applies to a substance or essence of a "thing" object or matter. The law is also referred to as subjective as a result.

The category of substantive administrative law is naturally not defined in normative terms or expressly separated as a distinct set of regulations. It is a doctrinal notion, a name for an element of administrative law's internal structure. Distinguishing characteristic, is its fundamental role in determining an individual's status in a state and their relations with public authorities. It is the substantive law norms that generate an individual's legal interests and construct public rights that place an individual in the position of public administration customer capable of demanding specific conduct, instead of a public authority customer subject to its fully free (discretionary) actions. Although substantive law is not addressed to administering entities, their duty to respect means it also affects conduct of public authorities. With regard to functions of substantive law, therefore, it appears reasonable to see it as not only shaping legal status of an individual but also as a kind of regulator of public administration's conduct ${ }^{21}$.

Substantive administrative law is not homogeneous owing to its internal diversity. It comprises, i.a., the exceptionally extensive area of personal law (e.g. questions of nationality, population register, law on foreigners), healthcare, protection against domestic violence or welfare legislation. Substantive administrative law also concerns regulations of land planning and development, construction or real estate administration, university education, national defence, and environment protection. In view of its complexity, substantive administrative law is the part of public legislation that determines an individual's position most fully.

It has already been emphasized factors inspiring (triggering action of) but also limiting (restricting or blocking) a legislator in creating regulations of substantive administrative law also include established international standards, including European standards, in particular those referring to human rights. They are not always expressed as part of legal provisions and are commonly found, e.g., in supranational pacts or declarations.

The Council of Europe's legislation - classic international law, though of regional extent - affects domestic laws of European states less intensely or effectively $^{22}$ than the EU legislation. This is so for two reasons. First, the scope of its regulation is narrower than of the EU legislation. This is primarily a human

${ }^{21}$ J. Jagielski, Rozważania nad pojęciem i istota prawa ..., p. 3.

${ }^{22}$ See J. Jaskiernia, Prawo Rady Europy a prawo krajowe - granice $i$ wspólne obszary, [in:] Prawo międzynarodowe, prawo europejskie i prawo krajowe - granice i wspólne obszary. Ksiegga jubileuszowa dedykowana Profesor Genowefie Grabowskiej, red. B. Mikołajczyk, J. Nowakowska-Małusecka, Katowice 2009, p. 254. 
rights protection legislation ${ }^{23}$. Secondly, it lacks such diversified and effective legal mechanisms of influencing internal laws of its signatory states as EU legislation has $^{24}$. Nonetheless, its impact is significant. The Council of Europe commenced its work on administrative law quite early, in 1977, when the first resolution was issued concerning protection of individual rights in relation to administrative acts of authorities ${ }^{25}$.

Signing and ratification of conventions prepared by the organization are the basic mechanisms whereby states become bound by the Council of Europe's standards, since the treaty legislation has a considerable effect on domestic substantive administrative law. Provisions of the Convention for the Protection of Human Rights and Fundamental Freedoms ${ }^{26}$ and especially standards created by the European Court of Human Rights in Strasbourg, are important in this connection.

Some comments inevitably need to be made on "the jewel in the Council of Europe's crown" here, since the Convention for the Protection of Human Rights and Fundamental Freedoms has the pride of place in the system of the organization's international agreements. First of all, in principle it applies not to relations among states party to the Convention but to individual rights and freedoms (law-making treaty); second, it determines states' obligations in the vertical arrangement of the state - individual; third, its provisions are highly effective, which ensures an individual's direct access to the European court (individual complaint) and a mechanism for enforcing decisions of the European Court of Human Rights; fourth, it is:

[...] an act penetrating into internal member state systems as it applies to disputes (governed by international law) between individuals and member states (for which the European Court of Human Rights is competent), but also, directly or indirectly, to disputes between individuals and public authorities within the particular states [...] which are resolved by domestic courts ${ }^{27}$.

${ }^{23}$ A. Wiśniewski, Koncepcja marginesu oceny w orzecznictwie Europejskiego Trybunału Praw Człowieka, Gdańsk 2008, pp. 38-40.

${ }^{24}$ A. Wróbel, Europeizacja prawa administracyjnego - pojęcie i konteksty, [in:] System Prawa Administracyjnego, t. 3, p. 19.

${ }^{25}$ Resolution (77)31 on the protection of the individual in relation to the acts of administrative authorities adopted on 28 September 1977 by the Committee of Ministers of the Council of Europe at the $275^{\text {th }}$ meeting of the Ministers' Deputies, [in:] Principles of Administrative Law Concerning the Relations between Administrative Authorities and Private Persons, Strasbourg 1996, pp. 236-241.

${ }^{26}$ Poland signed the convention on 26 November 1991, that is, the day it joined. It was ratified on 15 December 1992 and became effective on 19 January 1993 (Journal of Laws No. 61, item 284 as amended) as ratification documents were submitted to the Council of Europe's Secretarary General. See on this topic N. Szczęch, Konsekwencje prawne objęcia Rzeczypospolitej Polskiej kognicja Europejskiego Trybunału Praw Człowieka, [in:] Rada Europy a przemiany demokratyczne ..., p. 199.

27 D. Miąsik, A. Wróbel, [in:] System Prawa Administracyjnego, t. 3, pp. 46-47. 
The Convention for the Protection of Human Rights and Fundamental Freedoms is the top contemporary standard for protection of human beings, influencing domestic legislation of the Council of Europe member states since legislation of each state must conform to its international legal obligations. As a consequence, no area of law that governs a legal position of a human being to any extent can ignore the Convention. It obviously applies to substantive administrative law - the most extensive branch of law that is of extraordinary importance to citizens as it comprises norms relative to their everyday lives, defining and guaranteeing discharge of their rights and duties.

Emergence of the idea of universal protection of human rights and fundamental freedoms has made the individual the central reference point in assessment of actions by public administration not only in the domestic, but also European and global dimensions. The individual has gained legal capacity both in the field of substantive law but also in the procedural dimension as it has been granted the right to act not only against the state whose citizen it is but also against governments of other states that breach its rights and freedoms. The right to trial - which in the Polish system denotes the right to administrative trial with regard to interference of domestic public administration with individual rights - has been considerably extended with the European right to a fair trial, that is, the capacity to file a complaint with the European Court of Human Rights ${ }^{28}$.

It has been indicated above complexity of substantive administrative law enforces a selection of its areas which are influenced by the Council of Europe's legislation. Important issues are focused on, considering matters of the essence to individuals and their contacts with public administration. These comprise administrative personal law, concerning every human being and covering problems of nationality ${ }^{29}$, foreigners or collective law, among others.

Nationality issues in domestic law are governed by Act of 2 April 2009 on the Polish Nationality ${ }^{30}$ replacing the Act of 15 February 1962 on the Polish Nationality $^{31}$, found inadequate to new international standards. Even though a number of amendments to the latter had proved insufficient, work to adept the new law was relatively long. The current Act is based on the principles ${ }^{32}$ adumbrated in the European Convention on Nationality ${ }^{33}$ of 6 November 1997, which Poland

${ }^{28}$ M. Stahl, Od obywatela do człowieka. Kilka refleksji w kwestii przemian w relacjach między jednostka a władza publiczna, [in:] Między tradycją a przyszłością w nauce prawa administracyjnego..., p. 663.

${ }_{29}$ See more P. Ura, Obywatelstwo w świetle prawa administracyjnego, „Zeszyty Naukowe Uniwersytetu Rzeszowskiego. Seria Prawnicza” 2014, nr 84, pp. 181-201.

${ }^{30}$ Consolidated text Journal of Laws of 7 February 2017, item 1462.

31 Consolidated text Journal of Laws 2000, No. 28, item 353 as amended.

${ }^{32}$ In particular, the principle proclaiming each human being's right to nationality.

${ }^{33}$ European Treaty Series No. 166. The Convention attempts to coordinate actions of states intended to remove negative developments or resolve disputable questions of nationality, e.g. liq- 
has signed yet has as yet failed to ratify. As D. Pudzianowska points out, a range of specific solutions in the Polish Act are justified by reference to the principles of the European Convention on Nationality (e.g. the provision that resignation from nationality cannot lead to cases of statelessness or introduction of a new way of acquiring nationality by adoption). Addition of a voivode competence of recognising as Polish citizens certain categories of foreigners subject to the Code of Administrative Procedure is particularly noteworthy. This is in agreement with provisions of the European Convention on Nationality ${ }^{34}$. Contrary to the earlier times of totalitarian regime, when nationality meant subordination of individuals to the state, the new formula of Polish nationality incorporated in the Polish Nationality Act is a legal relationship modeled after solutions of present-day democratic states and international European regulations ${ }^{35}$.

It should be pointed out the European Convention on Nationality was the first of international treaties to introduce a definition of nationality ${ }^{36}$ based largely on the traditional construction of nationality as an institution of internal state law and, thus, designated certain possible regulations without imposing detailed solutions on individual states, however. Issues of nationality are also the subject of the Council of Europe's soft law documents including Resolution of the Council of Europe's Committee of Ministers ResAP (2001)3 on attempts towards full citizenship of persons with disabilities through inclusive new technologies ${ }^{37}$ and Committee of Ministers' Recommendation CM/Rec(2009)13 to member states on the nationality of children ${ }^{38}$.

uidate cases of statelessness or regulate double nationality. It should be remembered the Council of Europe's treaty legislation does not limit regulations connected with nationality to this international agreement. These issues have also been addressed by the Convention on the Reduction of Cases of Multiple Nationality of 6 May 1963 (European Treaty Series No. 043), guided by the idea of reducing, as far as practicable, cases of multiple nationality, setting out the procedure for acquisition of a new nationality or resignation from a nationality, and legal consequences of such decisions for the parties concerned, including children.

${ }^{34}$ D. Pudzianowska, Obywatelstwo w procesie zmian, Warszawa 2013, p. 240.

${ }^{35}$ See more on nationality from the international legal perspective in W. Czapliński, Międzynarodowe aspekty obywatelstwa, „Ruch Prawniczy, Ekonomiczny i Socjologiczny” 1984, nr 3, pp. 95-113; E. Dynia, Obywatelstwo w świetle prawa międzynarodowego, „Annales UMCS sectio G (Ius)” 2000, t. 47 , pp. 23-24.

36 Article 2 (a) defines 'nationality' as a relationship between a person and a state without indicating the person's ethnic origin. Article 3 stipulates that: " 1 . Legislation of each state defines who is its citizen. 2. The legislation will be accepted by other states insofar as it conforms to international agreements, international customary law, and universally acceptable legal principles of nationality".

37 Resolution ResAP(2001)3 Towards full citizenship of persons with disabilities through inclusive new technologies, adopted by the Committee of Ministers, on the 24 October 2001 at the $770^{\text {th }}$ meeting of the Ministers' Deputies.

${ }^{38}$ Recommendation $\mathrm{CM} / \operatorname{Rec}(2009) 13$ of the Committee of Ministers to member states on the nationality of children, adopted by the Committee of Ministers on 9 December 2009 at the $1073^{\text {th }}$ meeting of the Ministers' Deputies. 
In G. Krawiec's opinion, the Council of Europe is anxious for ensuring correct relations between the state and the individual. An individual should be provided a comprehensive legal protection capable of assuring a maximum extent of citizenship ${ }^{39}$.

Foreigner issues are another area of the analysis. A direct reference to the Convention for the Protection of Human Rights and Fundamental Freedoms ${ }^{40}$ is made in the Act of 13 June 2003 on Protection of Foreigners in the Republic of Poland ${ }^{41}$. The new regulations concerning protection of foreigners in the area of Poland are not only a result of Poland's undertaking to adapt its legislation to requirements of the European Union but also relates to an urgent need to normalise these questions which had been regulated only partly or constituted "legal gaps" under the preceding legislation. The latter include full normalisation of the legal situation of individuals who have not secured the status of refugees yet extradition to their countries would be contrary to the Convention for the Protection of Human Rights and Fundamental Freedoms. The Act of 1997 on Foreigners did envisage them applying for temporary residence permits, however, its long and complex procedure rendered the provision virtually dead. Therefore, the Polish foreigner legislation needed a new institution of the so-called tolerated residence permit ${ }^{42}$, introduced by force of a 2003 amendment to the Act ${ }^{43}$. In light of the then Article 3 of the Act on Protection of Foreigners in the Republic of Poland, a foreigner was allowed protection by being granted refugee status, asylum, tolerated residence permit, and temporary protection. Under the current provisions, on the other hand, the protection is given by: granting of refugee status, of subsidiary protection, asylum, and temporary protection.

The Council of Europe's other documents also govern issues of foreigners' legal status, for instance, the Convention of 5 February 1992 on the Participation of Foreigners in Public Life at Local Level ${ }^{44}$, which provides for participation of foreigners from third-party states in local elections ${ }^{45}$. As "the conscience of Europe",

39 G. Krawiec, Europejskie prawo administracyjne, Warszawa 2009, p. 178.

40 Article 1 of the Convention guarantees rights and freedoms (treated as subjective rights) to each individual subject to jurisdiction of a state party to the agreement regardless of whether the individual is a citizen of that state or a foreigner - citizen of another state (no matter if the latter state is party to the agreement) or a stateless person.

${ }^{41}$ Consolidated text Journal of Laws of 10 May 2018, item 1109. See A. Fermus-Bobowiec, E. Lis, Udzielanie ochrony międzynarodowej cudzoziemcom na terytorium Rzeczypospolitej Polskiej, „Studia Iuridica Lublinensia” 2016, nr 4, DOI: http://dx.doi.org/10.17951/sil.2016.25.4.25, pp. 25-59; M. Szuniewicz, Deportacja cudzoziemców w świetle zobowiąań Europejskiej Konwencji Praw Człowieka, „Polski Rocznik Praw Człowieka i Prawa Humanitarnego” 2014, nr 5, pp. 91-115.

${ }^{42}$ K. Cuadrat-Grzybowska, Nowe prawo o cudzoziemcach, „Monitor Prawniczy” 2003, nr 21, p. 111.

43 Journal of Laws 2003, No. 128, item 1176.

${ }^{44}$ European Treaty Series No. 144.

45 A. Bodnar, A. Ploszka, Rozszerzenie czynnego i biernego prawa wyborczego w wyborach samorzadowych na osoby nieposiadajace obywatelstwa Unii Europejskiej, „Samorząd Terytorialny” 
the organization makes pronouncements about European development and seeks solutions to new challenges brought by development of the European community. It directs its recommendations to the Committee of Ministers, inspiring conventions on specific issues, for example. The Parliamentary Assembly seeks consensus on directions of the European development and instruments to achieve intended objectives $^{46}$. The Parliamentary Assembly's Recommendation of 24 January 1996 concerning Albanians applying for asylum from Kosovo ${ }^{47}$, the Parliamentary Assembly's Recommendation of 29 January 1998 - Bosnia and Herzegovina: the return of refugees and displaced persons ${ }^{48}$, the Parliamentary Assembly's Recommendation of 2000 - the conflict in Chechnya ${ }^{49}$ - may serve as examples.

The Polish administrative collective law is not indifferent to the standards created by the Council of Europe either. In order to assure freedom of assembly, Poland has ratified the Convention for the Protection of Human Rights and Fundamental Freedoms, whose Article 11 guarantees freedom of peaceful assembly and assumes this freedom cannot be subject to other than statutory restrictions necessary in a democratic society for reasons of state or public security, protection of order and prevention of crime, protection of health and morality or of rights and freedoms of other persons. The Convention allows for legal limitations to the right to assembly to be imposed by members of the military, police or state administration. Exercise of the freedom of assembly and its restrictions are governed in Poland by the Act of 24 July 2015 -Assembly Law ${ }^{50}$. The principal reason for the new Assembly Law ${ }^{51}$ was the need for comprehensive and consistent regulation of rules and methods of organizing and holding assemblies with particular respect to not only constitutional but also international standards, including the rights guaranteed by the Convention for the Protection of Human Rights and Fundamental Freedoms ${ }^{52}$.

2013, nr 9, pp. 66-74; S. Łodziński, D. Pudzianowska, M. Szaranowicz-Kusz, Prawa wyborcze dla cudzoziemców - tak czy nie? Analiza procesu przyznawania praw wyborczych na poziomie lokalnym cudzoziemcom z państw trzecich w wybranych krajach Unii Europejskiej, Warszawa 2014.

${ }^{46}$ E.B. Haas, Consensus Formation in the Council of Europe, London 1960, pp. 34.

47 Recommendation 1288 (1996). Albanian asylum-seekers from Kosovo, https://assembly.coe. $\mathrm{int} / \mathrm{nw} / \mathrm{xml} / \mathrm{XRef} / \mathrm{Xref}-\mathrm{XML} 2 \mathrm{HTML}-\mathrm{en}$. asp?fileid=15322\&lang=en [access: 12.01.2020].

${ }^{48}$ Recommendation 1357 (1998). Bosnia and Herzegovina: return of refugees and displaced persons, www.assembly.coe.int/nw/xml/XRef/Xref-XML2HTML-en.asp?fileid=16583\&lang=en [access: 12.01.2020].

${ }^{49}$ Recommendation 1444 (2000). The conflict in Chechnya, http://assembly.coe.int/nw/xml/ XRef/Xref-XML2HTML-en.asp?fileid=16772\&lang=en [access: 12.01.2020].

${ }^{50}$ Consolidated text Journal of Laws of 7 February 2018, item 408. See also W. Kotowski, Ustawa z dnia 24 lipca 2015 r. - Prawo o zgromadzeniach (Dz.U. z 2015 r., poz. 1485). Komentarz, Bielsko-Biała 2015.

${ }^{51}$ It has replaced the Assembly Law of 5 July 1990 (consolidated text Journal of Laws 2013, item 397), many times amended and widely criticised.

${ }^{52}$ Statement of reasons for the draft Act ( $7^{\text {th }}$ term Parliament form No. 3518), www.sejm.gov. $\mathrm{pl} / \mathrm{sejm} 7 . \mathrm{nsf} / \mathrm{druk} . \mathrm{xsp}$ ?nr=3518 [access: 09.08.2018]. One should not ignore the fact the Assembly 


\section{CONCLUSIONS}

A state's membership of an international organization entails a variety of consequences. One of those is the need to adjust to the system of values and standards created by the receiving organization.

In light of the foregoing discussion, which only concerned certain selected areas, the Council of Europe can be said to play an important role in the process of transformation of substantive administrative law in Poland. By approving Council of Europe's axiology and fulfilling the statutory membership requirements, the Polish state realises standards of the organization, contained not only in the Convention for the Protection of Human Rights and Fundamental Freedoms and other conventions, but also in "soft law" documents. They may be alternatives to legally binding acts that enable the Council of Europe to affect its member states. In addition, they can be ancillary to those binding acts, supplementing or expanding their provisions. It should be noted the simultaneous application of binding and non-binding documents to a given area may also condition relations of qualified planned and unplanned complementarity.

By joining, therefore, Poland agrees to observe certain principles that govern relations between its authorities and private individuals, also in the area of substantive administrative law.

Support for the development of democracy in its member states is a priority of the Council of Europe. It is no accident the organization is referred to as "a pioneer and guarantee of protection of human rights and democracy" 53 or "the organization of values" ${ }^{54}$. The system of these values is extensive as it encompasses a range of areas of the European social and economic life, except for defence but including substantive administrative law. By means of its treaty law and soft law, the organization creates political guidelines for member state governments in such areas as nationality, foreigners or collective law. It continues to build the legal space in the face of the changing reality of Europe.

Law additionally realises guidelines laid down by the European Court of Human Rights in Strasbourg in its judgement of European Court of Human Rights in Strasbourg of 3 May 2007 in the case of Baczkowski and others vs Poland, application No. 1543/06, http://hudoc.echr.coe.int/eng?i=001-80464 [access: 09.08.2018].

53 The Council of Europe: Pioneer and Guarantor for Human Rights and Democracy, ed. R. Kicker, Strasbourg 2010.

${ }^{54}$ J. Jaskiernia, Rada Europy jako „organizacja wartości”, [in:] Wyjaśnianie polityki, red. J. Błuszkowski, J. Zaleśny, „Studia Politologiczne” 2010, t. 17, p. 178. 


\section{REFERENCES}

\section{Literature}

Balcerzak M., Zalecenia Komitetu Ministrów Rady Europy jako forma pozatraktatowej działalności normatywnej i harmonizujacej w dziedzinie praw człowieka, [in:] Rada Europy - 60 lat na rzecz jedności europejskiej, red. I. Głuszyńska, K. Lankosz, Bielsko-Biała 2009.

Bańczyk W., „Miękkie prawo, ale prawo”, czyli o obowiąku przestrzegania soft law, „Internetowy Przegląd Prawniczy TBŚP UJ" 2016, nr 1.

Bierzanek R., ,,Miękkie” prawo międzynarodowe, „Sprawy Międzynarodowe” 1987, nr 1.

Boć J., Uwagi o prawie administracyjnym w warunkach Unii Europejskiej, [in:] Prawo administracyjne, red. J. Boć, Warszawa 2010.

Bodnar A., Ploszka A., Rozszerzenie czynnego i biernego prawa wyborczego w wyborach samorzadowych na osoby nieposiadajace obywatelstwa Unii Europejskiej, „Samorząd Terytorialny” 2013, nr 9 .

Borchardt G.M., Wellens K.C., Soft Law in European Community Law, "European Law Review" 1989, Vol. 14.

Boyle A.E., Some Reflections on the Relationship of Treaties and Soft Law, "International and Comparative Law Quarterly” 1999, Vol. 48(4), DOI: https://doi.org/10.1017/S0020589300063739.

Cuadrat-Grzybowska K., Nowe prawo o cudzoziemcach, „Monitor Prawniczy” 2003, nr 21.

Czapliński W., Międzynarodowe aspekty obywatelstwa, „Ruch Prawniczy, Ekonomiczny i Socjologiczny" 1984, nr 3.

Dąbrowska A., Europeizacja materialnego prawa administracyjnego - wprowadzenie do problematyki, [in:] Złożoność materialnego prawa administracyjnego, red. J. Smarż, Radom 2018.

Dudzik S., Iwańska B., Kawka I., Przeksztatcenia materialnego prawa administracyjnego pod wptywem prawa europejskiego, [in:] System Prawa Administracyjnego, t. 3: Europeizacja prawa administracyjnego, red. Z. Hauser, Z. Niewiadomski, A. Wróbel, Warszawa 2014.

Duniewska Z., W kwestii czynników ksztattujących prawo administracyjne, [in:] Między tradycja a przyszłościa w nauce prawa administracyjnego. Ksiega jubileuszowa dedykowana Profesorowi Janowi Bociowi, red. J. Supernat, Wrocław 2009.

Dynia E., Obywatelstwo w świetle prawa międzynarodowego, „Annales UMCS sectio G (Ius)” 2000, t. 47.

Fermus-Bobowiec A., Lis E., Udzielanie ochrony międzynarodowej cudzoziemcom na terytorium Rzeczypospolitej Polskiej, „Studia Iuridica Lublinensia” 2016, nr 4,

DOI: http://dx.doi.org/10.17951/sil.2016.25.4.25.

Furrer H.P., Przekraczanie linii podziałów. Wydarzenia polityczne w Radzie Europy od 1989 r. - historia i analiza własnych doświadczeń, [in:] Polska i Rada Europy 1990-2005, red. H. Machińska, Warszawa 2005.

Haas E.B., Consensus Formation in the Council of Europe, London 1960.

Hoof G.J.H. van, Rethinking the Sources of International Law, Deventer 1983.

Iwiński T., Dyplomacja parlamentarna Rady Europy a rozwiazywanie konfliktów w państwach Europy Środkowej i Wschodniej, [in:] Rada Europy a przemiany demokratyczne w państwach Europy Środkowej i Wschodniej w latach 1989-2009, red. J. Jaskiernia, Torun 2010.

Izdebski H., Rola standardów Rady Europy $w$ dziedzinie organizacji i działania administracji publicznej, [in:] Polska i Rada Europy 1990-2005, red. H. Machińska, Warszawa 2005.

Jagielski J., Europeizacja prawa administracyjnego materialnego (na przykładzie prawa migracyjnego), [in:] Europeizacja polskiego prawa administracyjnego, red. Z. Janku, Z. Leoński, M. Szewczyk, M. Waligórski, K. Wojtczak, Wrocław 2005. 
Jagielski J., Rozważania nad pojęciem i istota prawa administracyjnego materialnego, [in:] System Prawa Administracyjnego, t. 7: Prawo administracyjne materialne, red. R. Hauser, Z. Niewiadomski, A. Wróbel, Warszawa 2012.

Jaskiernia J., Prawo Rady Europy a prawo krajowe - granice i wspólne obszary, [in:] Prawo międzynarodowe, prawo europejskie i prawo krajowe - granice i wspólne obszary. Ksiegga jubileuszowa dedykowana Profesor Genowefie Grabowskiej, red. B. Mikołajczyk, J. Nowakowska-Małusecka, Katowice 2009.

Jaskiernia J., Rada Europy jako ,, organizacja wartości”, [in:] Wyjaśnianie polityki, red. J. Błuszkowski, J. Zaleśny, „Studia Politologiczne” 2010, t. 17.

Jaskiernia J., Standardy Rady Europy a ustrój polityczny Polski, [in:] Polska w Radzie Europy. 10 lat członkostwa. Wybrane zagadnienia, red. H. Machińska, Warszawa 2002.

Jaskiernia J., Wpływ Rady Europy na proces transformacji w Polsce, [in:] Młode demokracje. 20 lat transformacji systemowej w Europie Środkowej. Płaszczyzna gospodarcza i polityczna, red. W. Saletra, J. Jarosiński, Kielce 2010.

Jaskiernia J., Znaczenie Zgromadzenia Parlamentarnego Rady Europy we wspieraniu demokracji w państwach członkowskich, „Europejski Przegląd Sądowy” 2017, nr 2.

Klebes H., Rola Zgromadzenia Parlamentarnego Rady Europy w upowszechnianiu standardów demokratycznych w Europie, [in:] Polska w Radzie Europy. 10 lat członkostwa. Wybrane zagadnienia, red. H. Machińska, Warszawa 2002.

Kotowski W., Ustawa z dnia 24 lipca 2015 r. - Prawo o zgromadzeniach (Dz.U. z 2015 r., poz. 1485). Komentarz, Bielsko-Biała 2015.

Krawiec G., Europejskie prawo administracyjne, Warszawa 2009.

Krawiec G., Europejskie standardy zwiąane z przebiegiem postepowania administracyjnego, „Roczniki Administracji i Prawa" 2011, R. XI.

Leoński Z., Materialne prawo administracyjne, Warszawa 2009.

Łodziński S., Pudzianowska D., Szaranowicz-Kusz M., Prawa wyborcze dla cudzoziemców - tak czy nie? Analiza procesu przyznawania praw wyborczych na poziomie lokalnym cudzoziemcom z państw trzecich w wybranych krajach Unii Europejskiej, Warszawa 2014.

Materialne prawo administracyjne, red. M. Miemiec, Warszawa 2013.

Miąsik D., Wróbel A., [in:] System Prawa Administracyjnego, t. 3: Europeizacja prawa administracyjnego, red. R. Hauser, Z. Niewiadomski, A. Wróbel, Warszawa 2014.

Nawrot O., Ludzka biogeneza w standardach bioetycznych Rady Europy, Warszawa 2011.

Pudzianowska D., Obywatelstwo w procesie zmian, Warszawa 2013.

Spryszak K., Rola standardów o charakterze soft law w zakresie kreowania zobowiazań w państwach czlonkowskich organizacji międzynarodowych, „Humanities and Social Sciences” 2017, nr 24(4), DOI: https://doi.org/10.7862/rz.2017.hss.77.

Stahl M., Od obywatela do człowieka. Kilka refleksji w kwestii przemian w relacjach między jednostka a władza publiczna, [in:] Między tradycja a przyszłościa w nauce prawa administracyjnego. Księga jubileuszowa dedykowana Profesorowi Janowi Bociowi, red. J. Supernat, Wrocław 2009.

Szczęch N., Konsekwencje prawne objęcia Rzeczypospolitej Polskiej kognicja Europejskiego Trybunału Praw Człowieka, [in:] Rada Europy a przemiany demokratyczne w państwach Europy Środkowej i Wschodniej w latach 1989-2009, red. J. Jaskiernia, Torun 2010.

Szuniewicz M., Deportacja cudzoziemców w świetle zobowiazań Europejskiej Konwencji Praw Człowieka, „Polski Rocznik Praw Człowieka i Prawa Humanitarnego” 2014, nr 5.

The Council of Europe: Pioneer and Guarantor for Human Rights and Democracy, ed. R. Kicker, Strasbourg 2010.

Ura P., Obywatelstwo w świetle prawa administracyjnego, „Zeszyty Naukowe Uniwersytetu Rzeszowskiego. Seria Prawnicza" 2014, nr 84.

Vel G. de, The Committee of Ministers of the Council of Europe, Strasbourg 1995. 
Wiśniewski A., Koncepcja marginesu oceny w orzecznictwie Europejskiego Trybunału Praw Człowieka, Gdańsk 2008.

Wróbel A., Europeizacja prawa administracyjnego - pojęcie i konteksty, [in:] System Prawa Administracyjnego, t. 3: Europeizacja prawa administracyjnego, red. Z. Hauser, Z. Niewiadomski, A. Wróbel, Warszawa 2014.

Wybór konwencji Rady Europy, Warszawa 1999.

\section{Legal acts}

Act of 15 February 1962 on the Polish Nationality (consolidated text Journal of Laws 2000, No. 28, item 353 as amended).

Act of 5 July 1990 - Assembly Law (consolidated text Journal of Laws 2013, item 397).

Act of 13 June 2003 on Protection of Foreigners in the Republic of Poland (consolidated text Journal of Laws of 10 May 2018, item 1109).

Act of 2 April 2009 on the Polish Nationality (consolidated text Journal of Laws of 7 February 2017, item 1462).

Act of 24 July 2015 -Assembly Law (consolidated text Journal of Laws of 7 February 2018, item 408).

Convention for the Protection of Human Rights and Fundamental Freedoms, Rome, 4 November 1950 (the Polish text: Journal of Laws 1993, No. 61, item 284 as amended).

Convention of the Council of Europe of 6 May 1963 on the Reduction of Cases of Multiple Nationality, European Treaty Series No. 043.

Convention on the Participation of Foreigners in Public Life at Local Level, Strasbourg, 5 February 1992, European Treaty Series No. 144.

European Convention on Nationality, Strasbourg, 6 November 1997, European Treaty Series No. 166.

Invitation to the Republic of Poland to Become a Member of the Council of Europe, Resolution (90)18 adopted by the Committee of Ministers, the 446th meeting of Ministers' Deputies, 23 October 1990.

Recommendation 1288 (1996). Albanian asylum-seekers from Kosovo, https://assembly.coe.int/nw/ $\mathrm{xml} / \mathrm{XRef} / \mathrm{Xref}-\mathrm{XML} 2 \mathrm{HTML}-\mathrm{en}$.asp?fileid=15322\&lang=en [access: 12.01.2020].

Recommendation 1357 (1998). Bosnia and Herzegovina: return of refugees and displaced persons, www.assembly.coe.int/nw/xml/XRef/Xref-XML2HTML-en.asp?fileid=16583\&lang=en [access: 12.01.2020].

Recommendation 1444 (2000). The conflict in Chechnya, http://assembly.coe.int/nw/xml/XRef/ Xref-XML2HTML-en.asp?fileid=16772\&lang=en [access: 12.01.2020].

Recommendation CM/Rec(2009)13 of the Committee of Ministers to member states on the nationality of children, adopted by the Committee of Ministers on 9 December 2009 at the $1073^{\text {th }}$ meeting of the Ministers' Deputies.

Resolution (77)31 on the protection of the individual in relation to the acts of administrative authorities adopted on 28 September 1977 by the Committee of Ministers of the Council of Europe at the $275^{\text {th }}$ meeting of the Ministers' Deputies, [in:] Principles of Administrative Law Concerning the Relations between Administrative Authorities and Private Persons, Strasbourg 1996.

Resolution ResAP(2001)3 Towards full citizenship of persons with disabilities through inclusive new technologies, adopted by the Committee of Ministers, on the 24 October 2001 at the $770^{\text {th }}$ meeting of the Ministers' Deputies.

Statement of reasons for the draft Act ( $7^{\text {th }}$ term Parliament form No. 3518), www.sejm.gov.pl/sejm7. nsf/druk.xsp?nr=3518 [access: 09.08.2018].

Statute of the Council of Europe, London, 5 May 1949, European Treaty Series No. 1 (the Polish text: Journal of Laws 1994, No. 118, item 565). 
Pobrane z czasopisma Studia Iuridica Lublinensia http://studiaiuridica.umes.pl Data: 26/04/2023 12:21:42

Influence of the Law of the Council of Europe on Substantive Administrative Law...

\section{Case law}

Judgement of European Court of Human Rights in Strasbourg of 3 May 2007 in the case of Baczkowski and others vs Poland, application No. 1543/06, http://hudoc.echr.coe.int/eng?i=001-80464 [access: 9.08.2018].

\section{STRESZCZENIE}

Kompetencje legislacyjne Rady Europy mają istotny wpływ na systemy prawa krajowego państw członkowskich, włącznie z materialnym prawem administracyjnym, a więc działem prawa administracyjnego regulującym prawa i obowiązki organów administracji publicznej i obywateli. Akty prawne tworzone przez organy organizacji mają znaczący wpływ na te obszary prawne, które wcześniej uważane były za wyłączną kompetencję wewnętrzną. Rada Europy zawsze była ważnym źródłem stanowienia standardów. W niniejszym artykule analizie poddano wybrane obszary materialnego prawa administracyjnego, biorąc pod uwagę dokumenty hard law i soft law opracowane pod auspicjami Rady Europy.

Slowa kluczowe: standardy Rady Europy; materialne prawo administracyjne; europeizacja materialnego prawa administracyjnego 